\title{
Bir Sulak Alan Nasıl Yönetilmez? Kültürel Ekolojik Perspektif ile Marmara Gölü (Manisa) Örneği
}

\author{
How not to manage a wetland? The case of Lake Marmara (Manisa) with a \\ cultural ecological perspective
}

\author{
Yılmaz Arı*, Bekir Derinöz \\ Balıkesir Üniversitesi, Fen-Edebiyat Fakültesi, Coğrafya Bölümü, Balıkesir
}

Öz: Bu çalışmanın amacı, Marmara Gölü örneğinde bir sulak alanın nasıl yönetilmemesi gerektiğini ortaya koymaktır. Bu amaçla Marmara Gölü kültürel ekolojisi incelenmis ve alanın, sulak alanların akılcı kullanımı konusundaki önemli gelişmelere karşın nasıl bu gelişmelerden uzak yönetildiği üzerinde durulmuştur. Bu anlamda sulak alan kullanımlarının eskiden beri değişimi, bu kullanımların sürdürülebilirliği, bu kullanımların alanın ekolojik işlevlerini ve ekonomik yararlllıklarını nasıl etkilediği araştırılmıştır. Bu çalışma aralıklarla 4 yıl süren saha çalışmalarına dayandırılmıștır. Marmara Gölü Türkiye'de az çalışılmış bir sulak alandır ve var olan çalışmalar da bütüncül olmaktan uzaktır. Önceki çalışmalarda gölün kültürel yapısı ve geleneksel insan-çevre ilişskisi ihmal edilmiştir. Bu çalışma bütüncül bir bakış açısı ile bu geleneksel iliş̧kiyi değerlendirmeyi amaçlamaktadır. Araştırma sonuçları Marmara Gölü Sulak Alanı ile yöre halkı arasında eskiden beri süregelen sıkı bir ilişsi olduğunu göstermiştir. Alan, Ramsar kriterlerini sağlayan uluslararası öneme sahip bir sulak alan olmasına karşın akılcı bir yönetim modeli ile yönetilmemiş̧ir. Su kaynaklarının gittikçe önem kazandı̆̆ günümüzde bu tür alanların özellikle Ramsar Sözleşmesi çerçevesinde geliştirilen akalcı kullanım prensipleri ile yönetilmesi zorunludur. Bu doğrultuda gerekli olan siyasal, teknik, idari ve yasal önlemler acilen alınmalıdır.

Anahtar Kelimeler: Sulak Alanlar, Kültürel Ekoloji, Sürdürülebilir Kullanım, Marmara Gölü.

\begin{abstract}
Te purpose of this study is to demonstrate how a wetland shouldn't be managed using the Lake Marmara in western Turkey. The cultural ecology of the area was investigated and the human impact on the ecosystem was examined. In this regard land-use change over time, sustainability of these uses, and the impact of this usage on the ecological and economical functions of the lake were investigated. The study is based on a fieldwork that extended over a four-year period. The Lake Marmara ecosystem is one of the least studied wetlands in Turkey and the previous studies have focused on certain aspects, lacking a holistic approach. This study aims at applying that holistic approach to study the traditional man-land relationship. The results showed that despite the importance of the area in terms of ecological and economical functions the area has not been managed with the wise-use principles developed by international conventions especially by the Ramsar Convention. In order to protect the wetland ecosystem better at Lake Marmara, a number of political, administrative, managerial, and legal measures should be introduced.
\end{abstract}

Key Words: Wetlands, Cultural Ecology, Sustainable Use, Lake Marmara.

\section{Giriş}

Girgin (2000) Ramsar listesine dahil edilmemiş olan sulak alanlarımızdan Marmara Gölü'nü incelemiş ve gölün, çevresindeki tarım alanlarından kaynaklanan besin tuzları girişi nedeniyle ötrofikasyon; kanalizasyon atıkları nedeniyle kirlilik ve düzenleme çalışmaları nedeniyle de su rejimi ile ilgili problemleri olduğunu tespit etmiş; alanın korunması yönündeki çalışmalara ağırlık verilmesi gerektiğini belirtmiştir. Adaman vd. (2009) ise Burdur Gölü’nün Ramsar Sözleşmesi çerçevesinde korunan bir alan olmasına karşın, alandaki doğa koruma çalışmalarının uluslararası, ulusal ve yerel

\footnotetext{
* İletişim Yazarı: Y. Arı, e-posta: yari@balikesir.edu.tr
} 
ölçekte etkin bir yönetim modeli geliştirilememesinden dolayı başarısız olduğunu vurgulamışlardır. Türkiye'de Ramsar Sözleşmesi çerçevesinde korunan 13 sulak alan vardır. Ancak, korunması gereken uluslararası öneme sahip sulak alan sayısı çok daha fazladır. Bu alanların birçoğunda koruma statüsüne karşın doğal ortamları tehdit eden çok çeşitli unsurlar vardır. Genel anlamda sulak alanlara yönelen bu tür tehditler son 10 yılda Türkiye'de de akademik çevrelerin dikkatini çekmiş ve çok sayıda akademik çalışmaya konu olmuştur (Yazıcı ve Şahin 1999; Özesmi, 1999; Girgin, 2000; Karadeniz, 2000; Arı, 2003a, b; Yiğitbaşığlu, 2003; Gündoğdu vd., 2005; Çalışkan 2008; Gürbüz vd., 2008; Güney, 1992 ve 1995; Karadeniz et al., 2009). Bu çalışmaların sulak alanların korunmasına önemli katkıları olmuş, bazılarında da Ramsar sözleşmesinin sulak alanları korumadaki yetersizliklerine vurgu yapılmıştır (Ar1, 2006; Adams and Hutton, 2007; Adaman vd., 2009). Ramsar alanlarında doğa koruma ile ilgili önemli sorunlar varken, uluslararası öneme sahip olup da halen Ramsar listesine dâhil edilmemiş olan sulak alanlarda bu sorunlar daha da fazladır. Bu çalışma bu sulak alanlarımızdan biri olan Marmara Gölü’nü kültürel ekolojik açıdan değerlendirmeyi amaçlamaktadır.

Günlük yaşantımızda bataklık ya da sazlık olarak tanımlanan sulak alanlar aslında ekolojik özellikleri ve barındırdıkları canlı toplulukları nedeniyle büyük bir öneme sahiptir. Gerek ekolojik gerekse de ticari değeri yüksek, değişik türden canlıların yaşamasına olanak sağlayan sulak alanlar, tropikal ormanlarla birlikte yeryüzünün en fazla biyolojik üretim yapan ekosistemleridir (Williams, 1990; Görmez, 1997). Sulak alanların başta su kuşları olmak üzere çok zengin yaban yaşamını barındırmalarının yanı sıra, doğa için önemli işlevleri ve insanlar için ekonomik değerleri vardır (de Groot vd, 2005; Ar1, 2006).

Sulak alanlar yüzyıllar boyunca sıtma kaynağı olarak görüldüğünden, insanların buralardan uzak durduğu yönünde yaygın bir kanaat vardır. Sulak alan araştırmacıları, insanların yerleşmelerini ister sulak alan kenarlarında kursun, isterse sulak alanlardan uzakta yaşasınlar, bu alanlarla çok sıkı bağlar kurduklarını ancak son zamanlarda fark etmiştir (Tont, 2001; Tiril, 2006). Halbuki daha önce sulak alanların sadece yaban yaşamı için önemi ve ekolojik bazı fonksiyonları olduğu düşünülmekteydi. Bu farkındalığın oluşmasından sonra insanların eskiden beri sulak alanları nasıl kullandığı; bu kullanımın ne kadar sürdürülebilir olduğu ve hepsinden önemlisi de insan etkinliklerinin sulak alanların işlev ve değerlerini nasıl etkilediği önemli çalışma konuları olarak ortaya çıkmışır (Dugan, 1991; Turan, 2001). Bu nedenlerden dolayı, ulusal ve uluslararası kuruluşlar bu alanlarla ilgilenmeye başlamış ve buraların yönetimi ve kullanımı için düzenlemeler yapılmıştır. Bu düzenlemelerden bazıları sulak alanların işlev ve değerlerini olumsuz yönde etkilemiştir. Mesela dünyada olduğu gibi Türkiye'de de sulak alanların ortalama olarak yarısı kurutulmuştur (Özesmi, 1999). Türkiye'de 8 ha.'dan büyük sulak alanların kurutulması ancak 2005 yılında revize edilen Sulak Alan Yönetmeliği ile yasal olarak durdurulmuştur (Gürer ve Yıldız, 2008).

Sulak alanlarda yapılan düzenlemeler ve doğa korumaya yönelik etkinlikler, yerel coğrafi koşullar ve alanın geleneksel kullanımı bilinmediği, ya da yeterince dikkate alınmadığı veya birbiriyle ilişkileri anlamında düşünülmediği için çoğu kere istenen sonuçları üretememektedir. Bu bağlamda sulak alanların bütüncül bir yaklaşımla çalışılması ve bu ekosistemlerin hem ekolojik işlevlerinin hem de insanlarla ilişkilerinin derinlemesine anlaşılması gerekmektedir. Kültürel ekoloji, bu anlamda gerekli olan derinliği sağlayabilecek bir yaklaşım olduğu için bu çalışmanın kavramsal çerçevesini oluşturmuştur. Kültürel ekolojik perspektif daha önceki çalışmalardan birisinde (Arr 2003b) tanıtıldığ1 için burada ayrıca açıklayıcı bilgilere yer verilmemiştir.

Marmara Gölü'nün araştırma sahası olarak seçilmesinin nedeni, bu alanın Ramsar Sözleşmesi'nde belirlenen uluslararası öneme sahip sulak alan kriterlerinden bazılarını sağlamasının yanı sıra önemli işlev ve değerlere sahip olmasına karşın, herhangi bir koruma statüsünün olmamasıdır. Bu çalışma, Girgin'in çalışmasından (2000) sonra sulak alanlarla ilgili koruma faaliyetlerinin ve araştırmalarının arttı̆g 1 aradan geçen 10 yıl içinde hem alanda meydana gelen değişmeleri gözlemleyecek hem de alanı bu sürede sulak alanlarla ilgili çıkan yeni yasalar ve yaklaşımlar 1şığında yeniden değerlendirecektir. 
Bu bağlamda şu sorulara cevaplar aranacaktır. İlk çağlardan beri süregelen insan kullanımları Marmara Gölü’nün ekolojik fonksiyonlarını nasıl etkilemiştir ya da değiştirmiştir? Alandaki yaşam biçimleri dikkate alındığında, sürdürülebilir olan ve olmayan uygulamalar nelerdir? Marmara Gölü’nün sağlıklı bir ekosistemin özelliklerini kaybetmesine neden olabilecek tehditler nelerdir? $\mathrm{Bu}$ tehditlerin ortadan kaldırılabilmesi için alınması gereken önlemler nelerdir?

$\mathrm{Bu}$ araştırma sorularını cevaplamak için Marmara Gölü ve civarında aralıklarla 4 yıl süren saha çalışmaları yapılmıştır. Bu çalışmalarda Hoobs (1986)' un tarif ettiği yöntem kullanılarak gözlem ve mülakatlar yapılmıştır. Katılımcı gözlem yolu ile alanın yerel halk tarafından kullanımı ve kullanımın ekosistem üzerine olan etkileri tespit edilmeye çalışılmıştır. Açık uçlu sorularla yerel halkın sulak alan algısı ve muhtemel tehditler hakkındaki görüşleri ortaya konulmaya çalışılmıştır. Saha çalışmaları, ekosistemin yılın farklı dönemlerindeki durumunu gözlemleyebilmek için, kullanımların yoğun olduğu yaz döneminde ve yaban yaşamının gözlemlenebildiği ilkbahar ve sonbahar dönemlerinde yapılmıştır. 


\section{Marmara Gölü’nün Konumu ve Genel Coğrafi Özellikleri}

Marmara Gölü Ege Bölgesi'nde yer alan Manisa ili sınırları dâhilinde olup; Salihli, Gölmarmara ve Ahmetli ilçeleri arasında yer almaktadır. Denizden yüksekliği 79 metre olan gölün yüzölçümü yıl içindeki seviye değişimlerine bağlı olarak 3200 - 6800 ha. arasında değişmektedir (Şekil 1).

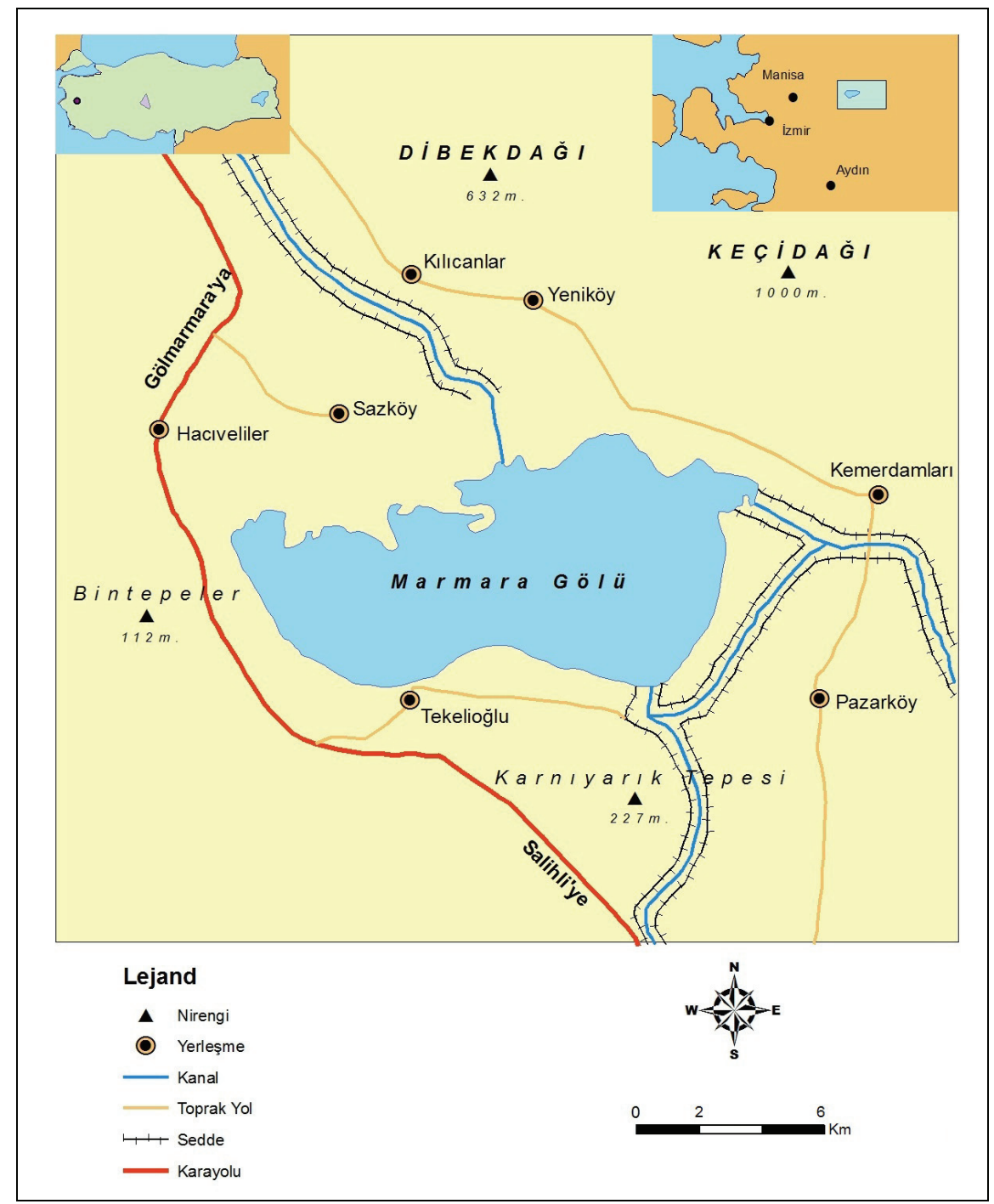

Şekil 1. Marmara Gölü’nün konum haritası

Gölün bulunduğu oluk, Gediz depresyonuna bağlanan bir çöküntü alanıdır. Kuzeybatıdan güneydoğuya doğru uzanan fayların sınırlandırdığı bu alanda, Menderes masifinin formasyonları ve alüvyonlar yaygındır (Hoşgören, 1983). Marmara Gölü'nün bulunduğu çukur saha güneyde, batıda ve kuzeyde tepelerle çevrili; doğuda Gediz Ovası'na, kuzeybatıda da Akhisar Ovası'na açıktır. Her iki ovadan da alüvyon setleriyle ayrılmıştır. İzbırak’a (1978) göre Marmara Gölü'ne bir set gölü karakteri veren de bu durumdur.

Marmara Gölü doğal bir set gölü olmasına karşın, yapay kanalları ve setleri aracılığıyla baraj gölü fonksiyonu kazanmıştır. Bu kanal ve setler kış aylarında önemli miktarda suyu toplamakta; sıcak ve kurak yaz aylarında ise tarım alanlarının sulanmasını sağlamaktadır (Şekil 2). Böylece sulak alana 
ekolojik işlevlerini kazandıran en önemli özelliklerinden biri olan mevsimsel salınım önemli ölçüde azalmaktadır.

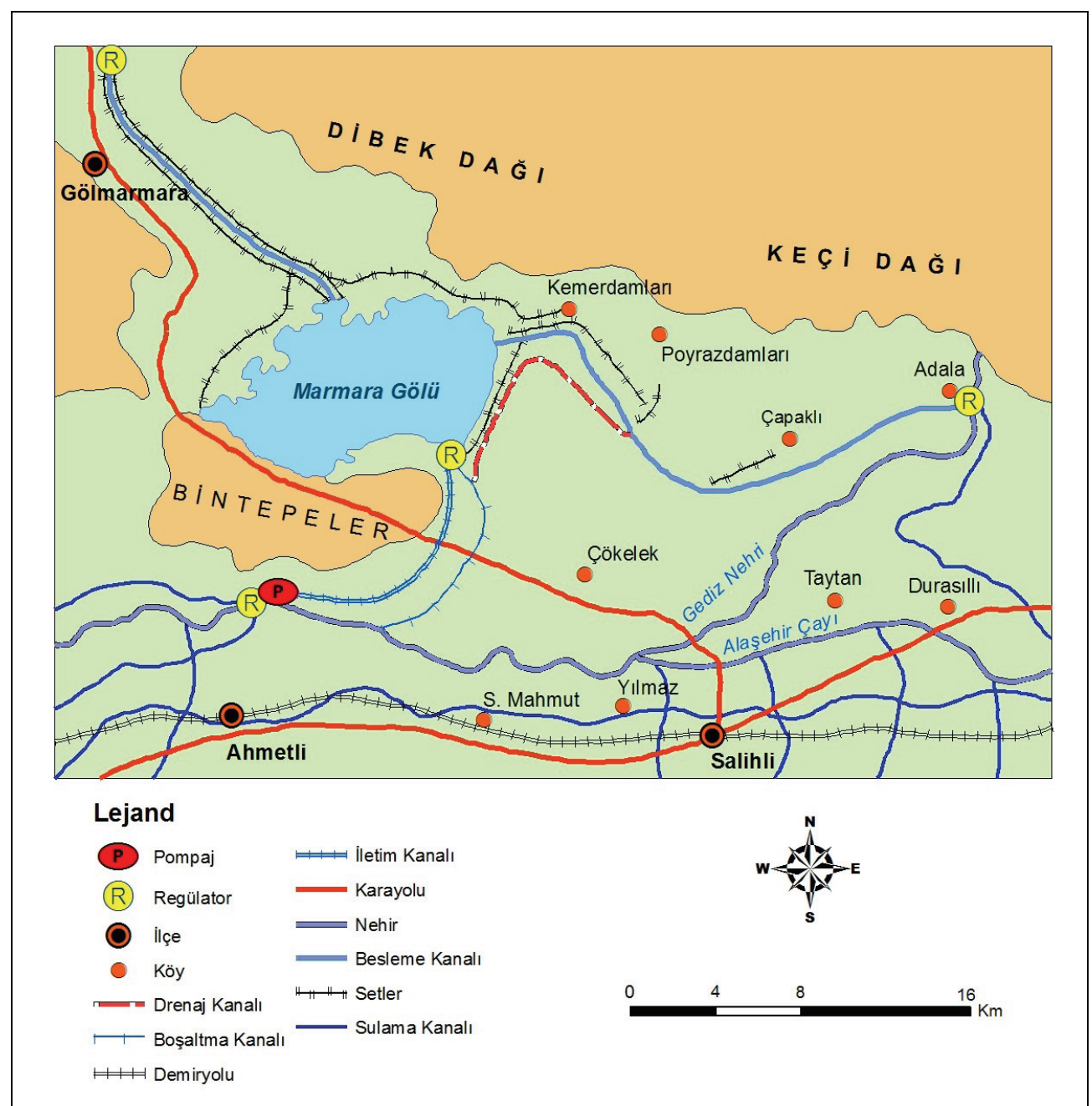

Şekil 2. Marmara Gölü çevresindeki kanallar (Girgin, 2000'den değiştirilerek)

Marmara Gölü civarındaki yerleşmelerde 15 000'e yakın nüfus yaşamaktadır. Nüfusun \% 70’i Gölmarmara ilçe merkezinde yaşarken, geri kalan kısmı da 10 köyde toplanmıştır. İlçe nüfusunun çoğunluğunu 1930-1950 yılları arasında yurdumuza gelen Balkan göçmenleri oluşturmaktadır. Yine 1950'li yıllarda Doğu Anadolu'dan göç eden nüfus Ozanca köyü ile merkez Kayapınar mahallesine yerleşmişlerdir. Ayrıca, zaman zaman çalışma amacıyla gelen geçici tarım işçilerinden de merkez İsmetpaşa ve Kayapınar mahallelerine yerleşenler olmuştur. Yörede Hacıbaştanlar, Kayaaltı, Dibekdere gibi Yörük köyleri de bulunmakla birlikte yerleşik yaşama yıllar önce geçen bu köylerde göçer kültürü hemen hemen hiç kalmamıştır. Yemek kültürleri de zamanla değişmiş, daha çok zeytinyağlı ve bitkisel yemekler benimsenmiştir. Ayrıca yöredeki Kılcanlar, Kemerdamları, Pazarköy ve Yeniköy'de yerel isimlendirmeyle 'manavlar' bulunmaktadır. Bunların, Anadolu'ya erken dönemlerde geldiği ve 17. yüzyıldan sonra da sahaya zorunlu olarak yerleştirildikleri tahmin edilmektedir. 
Sahadaki köylerden Gölmarmara’ya bağlı olan Hacıveliler, Kılcanlar, Yeniköy ve Taşkuyucak; Salihli'ye bağlı olan Kemerdamları, Pazarköy ve Tekelioğlu; Ahmetli'ye bağlı olan Yaraşlı, Dibekdere ve Kestelli köylerinin geçim kaynakları arasında bitkisel ve hayvansal üretim ön planda olup, bunlardan balıkçılık önemli bir yer tutmaktadır. Ayrıca göl etrafındaki yerleşmelerde gittikçe artan oranda sebze ve meyve üretimi görülmektedir.

1990, 2000 ve 2007 yılları karşılaştırmalı nüfus verilerine göre, Gölmarmara’nın 10 yıllık dönemde toplam nüfus artış hızı \% -3.81 olmuştur. Aynı oran, şehir merkezi bazında \% 2.06, köyler bazında ise \% -13.02 düzeyindedir (TÜİK, 2007). Bu verilerin 1şı̆̆ında, geçen 10 yıllık dönemde, genel olarak ilçenin toplam nüfusunda artış olmadığı, ancak şehir merkezinde nüfusun çok az arttığı, köylerde ise hızlı bir iç göçün görüldüğü söylenebilir (Çizelge 1).

Çizelge 1. Marmara Gölü çevresindeki yerleşmelerde seçilmiş yıllara göre nüfus durumu

\begin{tabular}{ccccc}
\hline Yerleşme & 1970 & 1990 & 2000 & 2007 \\
\hline Gölmarmara & 12654 & 10960 & 11036 & 9938 \\
Hacıveliler & 450 & 389 & 341 & 306 \\
Kılcanlar & 256 & 203 & 188 & 134 \\
Taşkuyucak & 667 & 614 & 599 & 507 \\
Yeniköy & 703 & 645 & 501 & 392 \\
Kemerdamları & 587 & 528 & 415 & 386 \\
Pazarköy & 598 & 500 & 440 & 385 \\
Ayanlar & 370 & 295 & 186 & 179 \\
Beyler & 367 & 310 & 292 & 260 \\
Çamköy & 401 & 307 & 211 & 186 \\
Çömlekçi & 329 & 284 & 220 & 183 \\
Hıroğlu & 300 & 209 & 155 & 128 \\
Değnekler & 787 & 702 & 618 & 594 \\
Hacıbaştanlar & 430 & 269 & 200 & 95 \\
\hline Toplam & 18899 & 16215 & 15402 & 13673
\end{tabular}

Kaynak: DİE (2000) ve TÜİK (2007) Genel Nüfus Sayımı Sonuçları

\section{Alandaki Geleneksel Yaşam Biçimleri}

\subsection{Tarım}

Çiftçilik, yörede ekonomik anlamda en önemli uğraştır. Yöre ekonomisi büyük ölçüde tarıma dayalıdır (Çizelge 2). Toprakları verimli olan bu alanda sulu tarım yapılmakla birlikte, sulama imkânlarının kısıtlı olduğu yerlerde de kuru tarım yapılmakta ve bu tür yerlerde daha çok buğday yetiştirilmektedir (Şekil 3). 
Çizelge 2. İlçenin arazi dağılımı

\begin{tabular}{cc}
\hline Cinsi & Miktarı (Da.) \\
\hline Tarım alanı & 97651.20 \\
Çayır-Mera & 1.900 \\
Orman-Fundalık & 128.940 \\
Yerleşim Yeri ve Tarıma Elverişsiz Arazi & 46.508 .80 \\
\hline Toplam & 275.000 \\
\hline
\end{tabular}

Kaynak: Gölmarmara Tarım-Kredi Koop., 2007

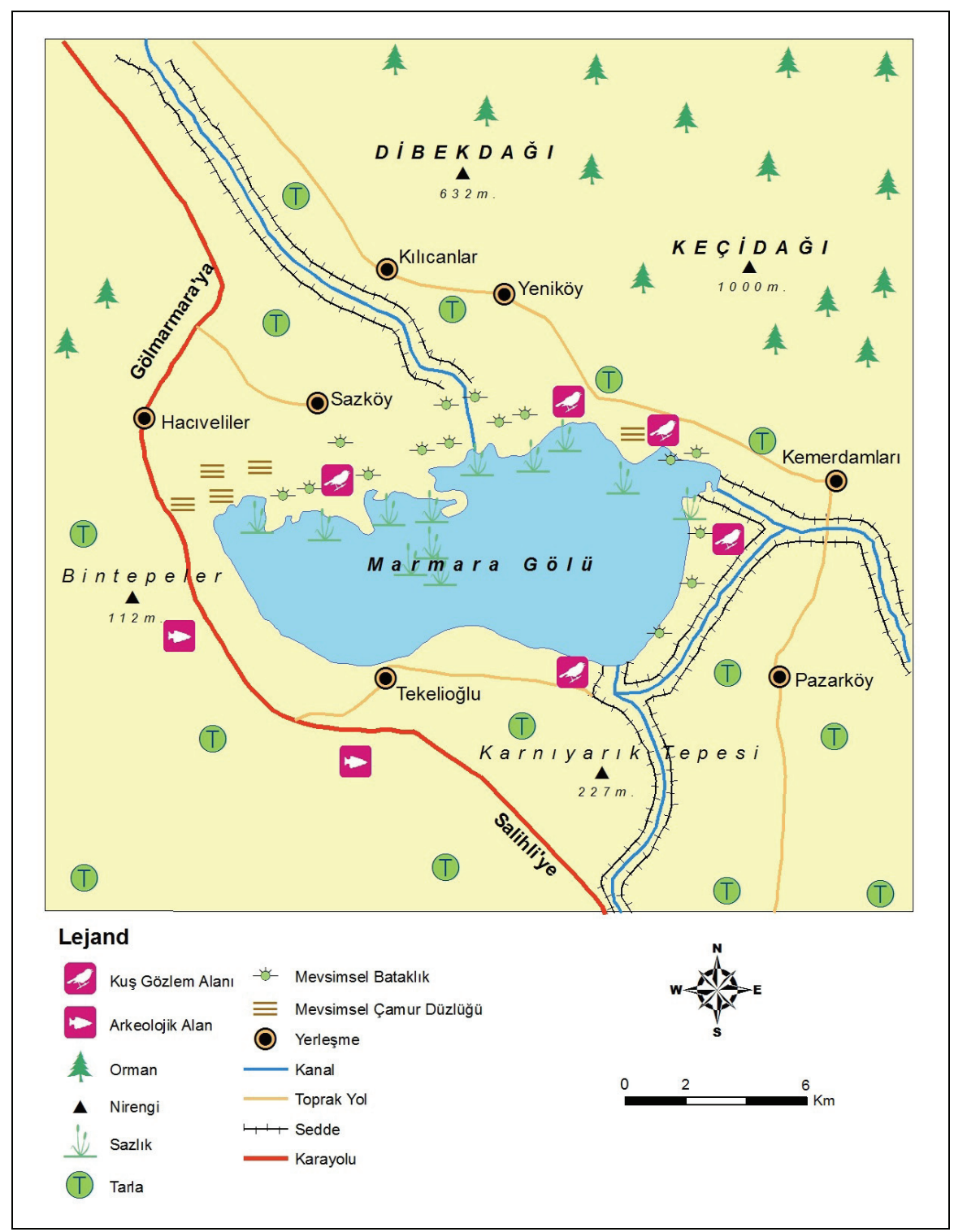

Şekil 3. Marmara Gölü’nde insan-çevre etkileşimleri haritası (Girgin, 2000'den değiştirilerek) 
Eskiden göl alanında su seviyesinin düşük olduğu dönemlerde ortaya çıkan ekolojik açıdan değerli alüvyal düzlükler ve bataklıklar çiftçiler tarafından kısa sürede tarım alanına çevrilmekteydi. Kısa süre su üstünde kalan bu alanlarda yetişme dönemi kısa olan kavun, karpuz, pamuk, sebze ve meyve tarımı, su seviyesi yükselinceye kadar yoğun biçimde yapılmaktaydı. Daha sonra bu alanların istimlâk edilmesiyle çiftçiler bu alanları kullanamaz hale gelmişlerdir. Eskiden özellikle göl kenarındaki kumluk alanlarda yoğun biçimde yetiştirilen ve yöre ekonomisinde önemli yeri olan kavun-karpuz tarımı günümüzde daha iç kesimlere kaymış durumdadır.

Günümüzde gölden tarım alanlarına doğru uzanan kanallar yazın bu alanları sulamakta ve tarımsal ürün deseninin çeşitlenmesini sağlamaktadır (Şekil 2). Çevredeki yüksekçe arazilerde daha ziyade üzüm ve zeytin yetiştirilirken, göl seddelerinin içinde ve dışında kalan düzlüklerde ise yoğun olarak pamuk tarımı yapılmaktadır. Sulanabilen alanlarda sebze (biber, domates, patlıcan vb.) yetiştiriciliği giderek yaygınlaşmaktadır. Diğer yandan ilçe ekonomisine olan önemli katkıları ve alanında ilk sıralara yükselme çabası sonucu, çalışma alanı içindeki hazine arazileri üzerinde her yıl artan oranda bostan (kavun ve karpuz) tarımına izin verilmektedir. Yöre bostan tarımında önemli bir yer edinmiştir. Yetiştirilen kavun ve karpuzlar, Gölmarmara'daki toptancı halinde ilk alıcılarıyla buluşmaktadır. Bu ürünler daha ziyade başta Almanya ve Hollanda olmak üzere Avrupa ülkelerine ihraç edilmektedir. Bostan tarımı yöreye o kadar damgasını vurmuştur ki, her yıl Ağustos ayının ilk Pazar günü Geleneksel Gölmarmara Kavun ve Karpuz Festivali düzenlenmektedir (Foto 1).

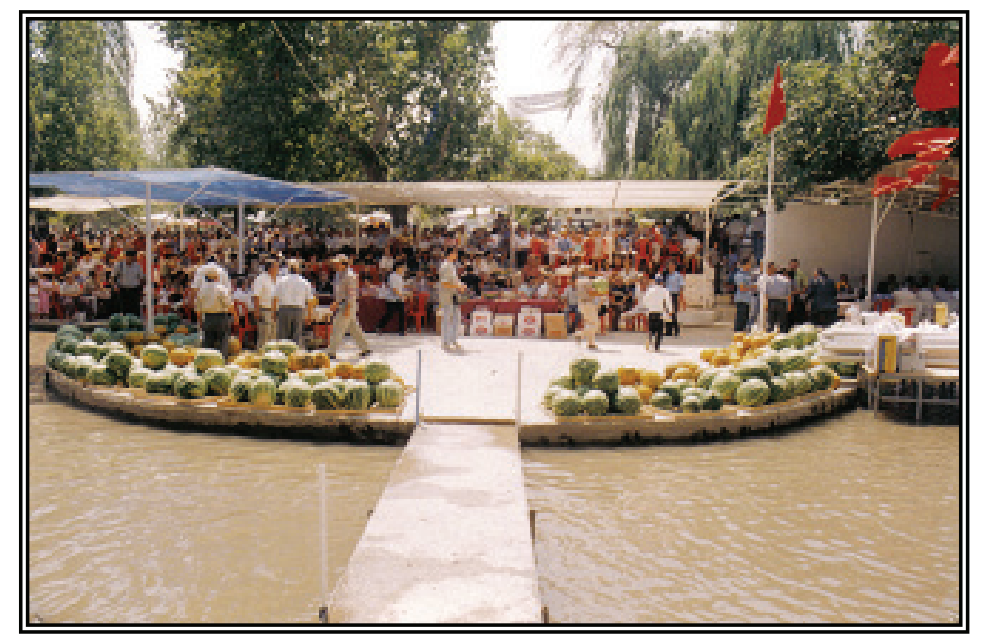

Foto 1. Geleneksel Gölmarmara kavun ve karpuz festivali

Ekolojik tarım da yörede önemli ölçüde yapılmaktadır. Ekolojik tarımın bu yöredeki öncüsü Marmara Gölü’nün güney kıyısındaki Tekelioğlu Köyü’dür. Yörede bağcılık, meyvecilik, pamuk üretimi ve hayvancılığın yanı sıra susam, bakliyat ve çeşitli tahılların dönüşümlü olarak ekildiği; kapari gibi doğadan toplanan bazı bitkileri de içeren ekolojik tarım yapılmaktadır. Burası, köyün neredeyse tamamı tarafından benimsenen ekolojik tarımın Türkiye'deki ilk örneklerinden biridir. Bu açıdan Tarım ve Köy İşleri Bakanlığı ile DSİ arasında bir protokol ile düzenlenen kullanma ve içme suyu havzalarının çevresindeki tarım arazilerinde ekolojik tarım yapmanın yararlarının gözlenebileceği bir örnek oluşturmaktadır. Bu tür tarım, bir Alman firması olan Rapunzel'in, 1976-85 yılları arasında Türkiye ile bu konuda işbirliği yapma isteğinin sonucu olarak ortaya çıkmıştır. Firma tarafından 1986 yılında Almanya'ya ihraç edilmek üzere ilk organik tarım projesi yapılmış ve kuru gıda üretimi gerçekleștirilmiştir. 1989 yılında İzmir'de ilk irtibat ofisini açan firma, aynı yıl içinde Tekelioğlu köyünde ilk organik köy projesini oluşturmuştur. Rapunzel firması, Tekelioğlu köyünde ekolojik tarım uygulamalarını teşvik etmekte ve üretilen ürünleri doğrudan Almanya ve Fransa'ya 
ihraç etmektedir. Bu köydeki çiftçiler bu şirket tarafından eğitilmekte ve zaman zaman Almanya'ya ilgili uygulamaları görmek üzere götürülmektedir. Ayrıca 2009 yılında Müşteri Ormanı Projesinin yaşama geçirilebilmesi amacıyla, şirket müşterilerinin 2008 yılı boyunca satın aldıkları her konteynır ve her Rapunzel personeli için doğum günü hediyesi olarak Tekelioğlu Organik Köyüne birer çam ağacı dikilmesi kampanyası başlatılmıştır. $\mathrm{Bu}$ projenin devam eden yıllarda da sürdürülmesi hedeflenmektedir.

Yörede 6200 dekar bağ alanı olup, 2007 yılı itibariyle bunun 5300 dekarı ekilmiş ve 1 dekardan ortalama $420 \mathrm{~kg}$. ürün alınmıştır. 2007 yılı toplam üretimi ise 29 bin ton civarındadır ve bunun 16 bin TL civarında girdi sağladığı kaydedilmiştir (Gölmarmara Tarım Kredi Koop., 2007).

Zeytin yetiştiriciliği de yöre ekonomisinde önemli bir yer tutmaktadır. Göl çevresinde yaklaşık 1690 dekar zeytin alanı olup, dekar başına üretim ortalama 1.7 ton civarındadır. Zeytin yetiştiriciliğinin 2007 yılı itibariyle 135 bin TL civarında girdi sağladığı kaydedilmiştir (Gölmarmara Tarım Kredi Koop., 2007).

Tütün ve pamuk da yetiştirilen diğer önemli ürünlerdir. Yörede pamuk ekilen alanlar 30000 dekarı bulmaktadır. Pamuk üretiminin fazla olması nedeniyle son yıllarda Salihli, Gölmarmara ve Ahmetli'de 4 adet çırçır fabrikası, 2 adet iplik ve dokuma fabrikası ve 3 adet tekstil fabrikası kurulmuştur. Pamuk tarımının yöreye 2.8 milyon TL civarında girdi sağladığı kaydedilmiştir (Gölmarmara Tarım Kredi Koop., 2007). Tütün ise yaklaşık 4300 dekar alana ekilmektedir. Yine bu üründen de, 1.7 milyon TL' yi aşan miktarda girdi sağlanmaktadır (Gölmarmara Tarım Kredi Koop., 2007). Şatıroba, Çiftlik ve Tatlıcak köyleri çevresindeki arazilerde ise daha ziyade şekerpancarı ve sulanabilen alanlarda da sebze tarımı yapılmaktadır (Çizelge 3).

Çizelge 3. Yöredeki tarımsal arazi kullanım çizelgesi

\begin{tabular}{cc}
\hline Tarım Alanı & Miktarı (Da.) \\
\hline İlçenin Toplam Tarım Alanı & 97.651 \\
Sulanabilir Alan & 49.087 \\
Tarla Alanı & 51.660 \\
Sebze Alanı & 25.594 \\
Meyve Alanı & 20.077 \\
\hline Toplam & 244.069 \\
\hline
\end{tabular}

Marmara Gölü’nün ötrofik bir göl haline gelmesinin en önemli nedeni bütün bu tarımsal etkinliklerde kullanılan fosfat ve potasyum gibi bitki besin tuzlarıdır. Göl çevresinde geleneksel tarım yöntemlerinden ticari tarım etkinliklerine geçildiğinde, bitki besin maddelerinin kullanımı denetimsiz bir şekilde artmıştır. Göl çevresindeki tarımsal arazilerde kullanılan bu gübreler ilaçlarla birlikte toprakta birikmekte ve özellikle yağışın bol olduğu kış aylarında yağmur sularıyla göle taşınmaktadır. $\mathrm{Bu}$ tuzlarla beslenen su bitkileri çabucak büyüyerek oksijen tüketmekte ve su içindeki çözünmüş oksijen ihtiyacı artmaktadır. Bu durum gölün ekolojik fonksiyonlarını önemli ölçüde etkilemektedir. İnsan kullanımları da bu sebeple ya kesintiye uğramakta, ya da değişmektedir.

\subsection{Balıkçılık}

Sulak alanda bulunan sazlıklar ve bataklıkların planktonlar ve omurgasız canlılar bakımından zengin oluşu, alanın zengin bir faunaya sahip olmasını sağlamıştır. Özellikle Sazan (Cyprinus carpio), Sudak (Sander lucioperca), Has Kefal (Mugu cephalus) ve Alabalık (Salmo trutta) türlerine ait zengin balık popülasyonları mevcuttur.

Sulak alanlar şüphesiz ki balık potansiyeli açısından son derece zengin alanlardır. Hatta, yapılan araştırmalar yediğimiz balıkların 2/3'sinin yaşamlarının tamamını ya da belirli bir devresini sulak alanlarda geçirdiğini göstermiş̧tir (Dugan, 1991; TÇSV, 1989). Bu nedenle, sulak alanlar balıkçılığın devamlılığı yönünden yaşamsal öneme sahiptirler. 
Marmara Gölü kenarında yer alan sazlıklar, özellikle balıkların yumurtlaması için uygun ortamlar oluşturmaktadır. Bilindiği gibi birçok balık türü yumurtladıktan sonra, yumurtadan çıan yavruları yemekte ve bu durum sonucunda $1 / 3$ oranında yavru balık azalması olmaktadır. İște bu sazlıklar, bir ölçüde bu durumu engellemektedir. Ancak, her yıl çeşitli amaçlarla toplam saz alanının yaklaşık \% 25'i kesilmektedir (Girgin, 2000).

Marmara Gölü'ndeki balıkçılık, Gölmarmara Su Ürünleri Üretim ve Değerlendirme Kooperatifi tarafından yürütülmektedir. Sazan, yayın, turna, yılan ve Marmara balığı avlanan balıklar arasındadır. 2007 yılı itibariyle $10272 \mathrm{~kg}$. sazan, $4342 \mathrm{~kg}$. havuz ve $846 \mathrm{~kg}$. da sudak balığ 1 avlandığ kaydedilmiştir (Çizelge 4). Sazan balığı üretimi, suyun durumuna göre değişmektedir. Su, kritik sınıra düştüğü zaman kiralama faaliyetleri dondurulmaktadır. 1981 yılından 1991 yılına kadar olan 10 yıl içinde balık üretimi sürekli olarak azalmıştır. 1991, 1992 ve 1993 yıllarında getirilen sürekli av yasağ1 ile aşırı avlanma önlenmeye çalışılmıştır (Girgin, 2000).

Çizelge 4. Marmara Gölü’nde balık üretimindeki değişmeler

\begin{tabular}{cccc}
\hline Y1l & Ton & Y11 & Ton \\
\hline 1932'den önce & 300 (tahmini) & $1991-92-93$ & Av Yasağ1 \\
1963 & 967 & 1994 & 50 \\
1977 & 191 & 1995 & 61 \\
1982 & 522 & 1996 & 125 \\
1984 & 36 & 2000 & 134 \\
1985 & 235 & 2003 & 90 \\
1989 & 236 & 2005 & 81 \\
1990 & 19 & 2007 & 45 \\
\hline
\end{tabular}

Kaynak: Gölmarmara Su Ürünleri Koop., 2007

Marmara Gölü oldukça sığdır. Derinliği yıldan yıla değişmekle birlikte ortalama 3-4 metre civarındadır. Bu durum, bol oksijen ve bol bitkisel besin üretimine imkân vermektedir. Özellikle kıyı bölgesinin mevsimlik genişlemeleri balıklar için uygun üreme alanları sağlamaktadır. Marmara Gölü'ndeki balık potansiyelinin bilinmemesi ve envanterinin çıkarılmamış olması ile birlikte, göle sadece balık salmak ve beslemekle yetinilmesi sonucunda 1991 yılında balıkçılık kesintiye uğramıştır. Gölün neredeyse kuruma noktasına geldiği 1993 yılında balıkçılık faaliyetleri adeta durmuştur. Ancak balıkçılık göl su seviyesinin yükselmesi ile yeniden canlanmıştır (Foto 2 ve 3). 

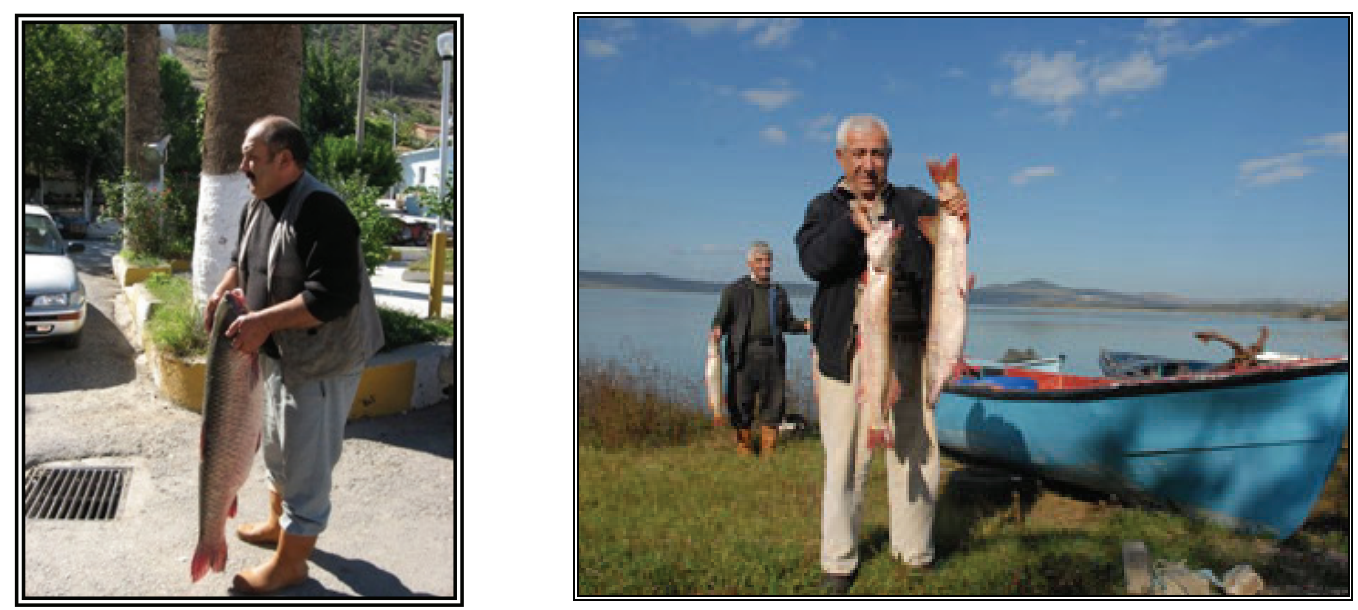

Foto 2 ve 3. Gölden avlanan bir sazan balığı (solda) ve göldeki balıkçılık faaliyetlerinden bir görünüş (sağda)

Yörede balıkçılık yapanların sayısı gün geçtikçe azalmaktadır (Foto 4 ve 5). Bunun yanı sıra yasa dışı balıkçılık yapanlar da vardır (Kambur, 2008). Salihli’ye bağlı olan Tekelioğlu Köyü'nde 1979 yılında kurulmuş olan Balıkçılık Kooperatifi'nin 200'ü aşkın ortağı ile av mevsiminde günde 800 kilograma kadar üretim gerçekleştirdiği kaydedilmiştir. Günümüzde ise bu miktar yıllara göre değişiklik göstermekle birlikte $120-150 \mathrm{~kg}$ civarındadır. Tekelioğlu Köyü’nde ikinci balıkçılık kooperatifi de 1987 yılında kurulmuştur. Daha ziyade eski kooperatiften ayrılan balıkçıların oluşturduğu bu yeni kooperatifin 325 üyesi ile günde 500-600 kg. üretim gerçekleştirdiği kaydedilmiştir. Ancak günümüzdeki üretim 100 tonu bile bulamamaktadır (Gölmarmara Su Ürünleri Koop., 2007).
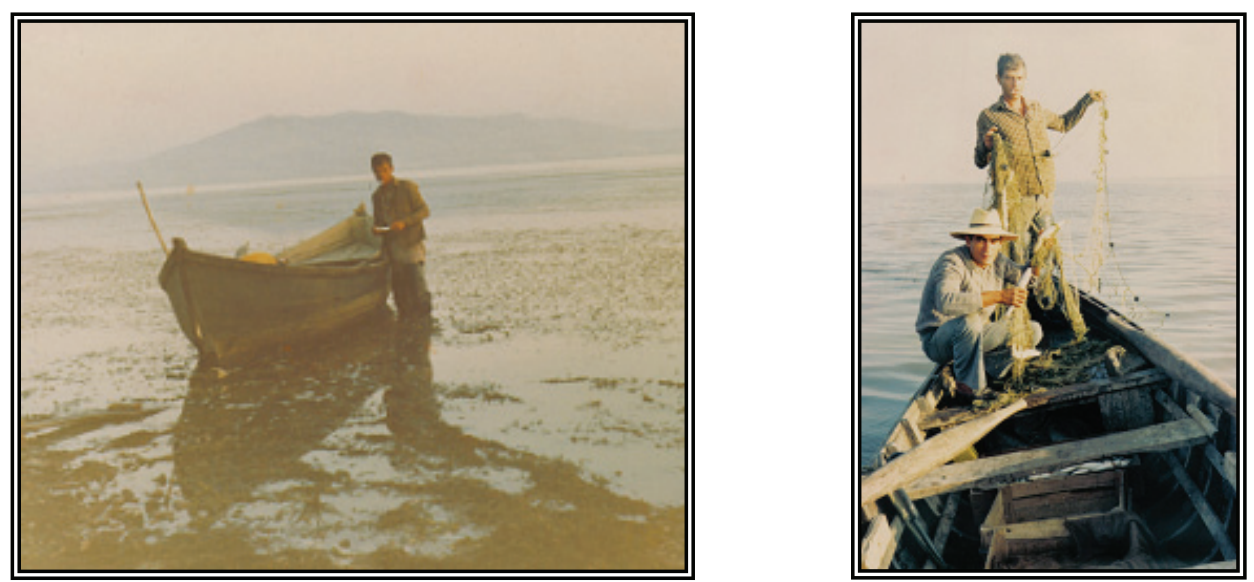

Foto 4 ve 5. Marmara Gölü Sulak Alanı'ndaki avlanma faaliyetlerinden bir görünüş 
Marmara Gölü doğal halinde iken yılda 300 tona yakın balık avlanmakta idi. Gölde su seviyesinin yükselmesi ile balıkçılık da gelişmiş, 400' ün üzerinde balıkçı teknesi işlemeye başlamış, en yüksek seviyeye ulaşılan 1963 yılında rekor düzeyde (963 ton) balık avlanmıştır (Gölmarmara Su Ürünleri Koop., 1990). Sulak alanın doğu bölümünde tutulan balık miktarı 1970'lerdeki 500 tondan, 1995 'te 125 tona kadar inmiştir. Batı bölümünde ise, büyük olasılıkla aşırı avlanma ve kirlilik nedeniyle balıkçılık sektörü önemli ölçüde zarar görmüştür.

Daha sonraki dönemde Su Ürünleri Üretim ve Değerlendirme Kooperatifi ile DSİ tarafindan göle sazan, sudak ve havuz balığı türlerinden oluşan yarım milyondan fazla yavru balık bırakılmış ve av yasağı getirilmiştir. Bunun sonucunda su seviyesinin de yükselmesi ile balık stoklarında artışlar ortaya çıkmıştır.

Günümüzde gölde değişik türde balıklar yaşamakla birlikte daha çok sazan balığı bulunmakta ve avlanmaktadır. Yöreden Ahmetli, Salihli ve Akhisar'a kadar balık gönderilmektedir. Avlanırken yem olarak daha ziyade canlı tatlı su balıkları, yapay yem ve kaşık kullanılmaktadır. Avlanma teknikleri olarak da canlı yem, ölü yem, çökertme, yüzdürme, çoklu çökertme, sürtme ve atıp-çekme gibi yöntemler kullanılmaktadır. Önceden olduğu gibi günümüzde de kaçak balık avcılığı hala sürmekte ve bu konuda kooperatif bünyesinde denetlemeler yapılmaktadır. Ayrıca İlçe Orman Mühendisliği ve Jandarma ekipleri bünyesinde oluşturulan av komisyonu, yeterli olmasa da denetimler yapmaktadır. Bunun yanı sıra denetimsiz avcılık ve çevredeki sanayi tesislerinden, tarım alanlarından gelen zararlı maddelerle meydana gelen kirlenme balık miktarını iyice azaltmıştır. Ayrıca amatör balıkçılar hiçbir kural tanımaksızın alanda zaman zaman avlanmaktadır. Aşırı su çekimi geçmiş dönemlerde göle oldukça ciddi zararlar vermiş, göl önemli oranda su kaybetmiştir. Daha sonra DSİ tarafından yapılan çalışmalarla göl eski haline getirilmeye çalışılmış; bunda bir ölçüde başarılı olunmuş ancak, göl bundan 20-30 yıl kadar önceki parlak dönemlerine bir daha döndürülememiştir.

Gölmarmara Ziraat Odası başkanı Erdal Ziyan, son yıllarda gölün içinde bulunmuş olduğu olumsuz durum ile ilgili olarak Marmara Gölü'nün aşırı kuraklık nedeniyle toplu balık ölümlerine sahne olduğunu ve 85 bin dönüm alana sahip olan gölün 20 bin dönüme gerilemesi sonucu çevrede bulunan köylülerin yaşam biçiminin değiştiğini ifade etmektedir. Gölde yaşanan aşırı kuraklık sonrası çekilen suların ortaya çıkardığı boş alanların tarım arazisi olarak köylünün hizmetine sunulduğunu belirten Ziyan, arazilerin açılan ihaleler sonucu köylüye verildiğini de belirtmektedir. Ziyan ayrıca göldeki su miktarının her geçen gün azaldığını ve şu an en derin yerin sadece 2 metre civarında olduğunu bildirmiştir. Gölmarmara'nın yağmur sularından başka önemli bir besleyici unsuru kalmadığı, kuraklık ve buharlaşma da hesaba katılırsa gölün 3-5 yıl içinde yeterli yağış düşmezse kuruyabileceği de ifade edilmektedir. Göl'ün köylü için önemli bir geçim kaynağı olduğu, eskiden Sazan balığıyla meşhur olan gölde önceki yıllarda yapılan balıkçılı̆̆ın köylerin ekonomisine büyük bir katkı sağladığı, geçimini balıkçılık yaparak sağlayan vatandaşların şu an başkalarının yanında yevmiye ile çalıştı̆̆ balıkçılığın neredeyse sona erdiği yöre sakinleri tarafından ifade edilmektedir. Ayrıca göldeki canlılardan sazan balıkları, midyeler, kurbağalar ve su yılanlarının suyun azalmasından önemli ölçüde etkilendiği ifade edilmektedir.

Yıllardır gölde balıkçılık yapan 67 yaşındaki Ferhat Gezgin (Hacıveliler) de gölün her geçen gün kuruduğunu, balıkların da çamurdan çıkamadığını, 80 bin dönümden daha fazla alan kaplayan gölün sularının giderek azaldığını ifade etmektedir. Balıkçı Ali Atıcı (Tekelioğlu) da, 2009 yazında balıkçılık faaliyetlerinde önemli bir azalma olduğunu ifade etmiştir.

Son olarak 19 Ekim 2009 tarihinde gölün avcılığa kapatılması için S.S. Gölmarmara ve Çevresi Su Ürünleri Kooperatifi (Göl-Koop) ile S.S. Pazarköy, Yeniköy, Kemerdamları ve Çevresi Su Ürünleri Kooperatiflerinin yazılı talepleri üzerine Tarım ve Köyişleri Bakanlığınca "Gölmarmara Göl'ündeki su kotu tekrar eski seviyesine ulaşıncaya ve göldeki su ürünleri populasyonu tekrar artıncaya kadar Gölmarmara Gölü her türlü su ürünleri avcıllı̆ına kapatılmıştır“" şeklinde bir karar alınmıştır.

Adı geçen su ürünleri kooperatiflerinin avlak saha kira sözleşmeleri İl Özel İdaresi’nce iptal edildiği ve bu nedenle $2 / 1$ numaralı ticari amaçlı su ürünleri avcıllğını düzenleyen tebliğin 44 . maddesi 
1. bendi gereği Gölmarmara Gölü’nde faaliyet gösteren su ürünleri kooperatiflerinin kiracılıklarının sona erdiği Manisa Valiliği Tarım İl Müdürlüğü’nün 18.12.2008 tarih ve 10922 sayılı yazıları ile bildirilmiş ve konu Gölmarmara İlçe Tarım Müdürlügü tarafindan 18.12.2008-31.12.2008 tarihleri arasında Belediye Başkanlığına ilan ettirilmiştir. Ancak yine de zaman zaman bu yasağa uyulmadığı şeklinde duyumlar alındığ yetkililer tarafından ifade edilmektedir.

Marmara Gölü’ndeki su ürünleri avcıllğı yasağı devam etmektedir. Gölde su ürünleri yasağına uymayanların, başta göl çevresindeki Yeniköy, Kılcanlar, Hacıveliler yerleşmeleri muhtarları veya vatandaşlar tarafindan görülmesi, duyulması ya da çeşitli sebeplerle tespiti halinde İlçe Jandarma Komutanlığı ile İlçe Tarım Müdürlügüne vakit geçirilmeden bildirilmesi ve avlanmaya izin verilmemesi karara bağlanmıştır. Yasakların uygulanması görevinin de İlçe Tarım Müdürlüğü ve Belediye Başkanlığı Zabıta Amirliği’nce yapılması kararlaştırılmıştır.

\subsection{Hayvancilik}

Hayvancılık yöre halkının geçiminde önemli bir yer tutmaktadır. Yörede hayvancılık, tarımdan sonra ikinci planda gelmektedir. Özellikle sulak alan çevresindeki köylerde hayvancılık daha yaygın olup, göl etrafında yaklaşı 1000 dekar mera alanı yer almaktadır.

Göl çevresinde su seviye değişimlerinin sık ve belirgin biçimde etkili olduğu subasar arazilerde önceden yöre halkı hayvanlarını (özellikle de büyükbaş) otlatmaktaydı. Ancak, daha sonra bu araziler istimlâk edilince hayvan otlatılması yasaklanmıştır. Nitekim gölün hızla sazlarla kaplanmasında ve açık su yüzeyi alanlarının daralmasında bu durumun etkisi vardır. Çünkü gölde otlayan hayvanlar sazlarla beslenirken, dolaştıkları sahalarda balık ve kuşların hareket edebileceği açık su yüzeylerinin açılmasına neden oluyorlardı. Yörede mera hayvancılığı yapan Mustafa Aktaş (Sazköy), "mera hayvancıllı̆̆nda genellikle et ve süt verimi daha az olan yerli ırklar yetiştiriyoruz, bizim için otlaklar önemli, mera hayvancillğ kötüleşiyor" diyerek duruma tepki göstermektedir.

Günümüzde gölün batı ve kuzeyinde bulunan çayırlık alanlarda genellikle büyükbaş hayvan otlatılmaktadır (Foto 6). Daha ziyade melez sığır türünün yetiştirildiği alanda yerli türler ikinci planda kalmıştır. Gölden uzaklaştıkça yapılan faaliyetlerde de değişmeler gözlenmektedir. Nitekim iç kesimlerdeki fundalık alanlarda genellikle küçükbaş hayvan beslenmektedir. Bunların başında koyun gelmekte ve az sayıda da kıl keçisi bulunmaktadır (Çizelge 5). 


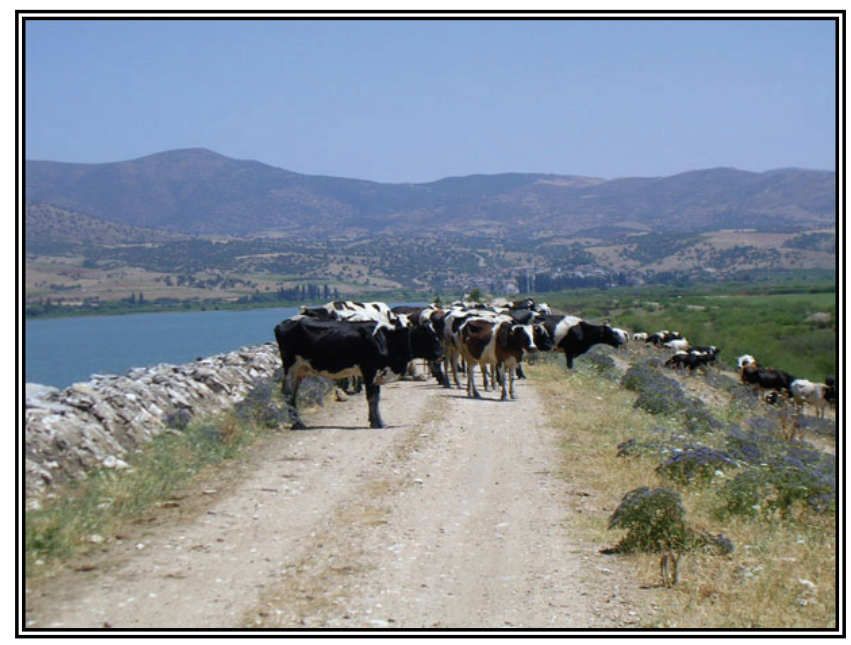

Foto 6. Marmara Gölü kenarında yapılan büyükbaş hayvancılık faaliyetlerinden bir görünüş

Çizelge 5. Yöredeki hayvansal üretim

\begin{tabular}{lccllc}
\hline \multicolumn{2}{c}{ Hayvan Varlığı } & $\begin{array}{c}\text { Sayıs1 } \\
\text { (Baş) }\end{array}$ & Hayvansal Ürünler & $\begin{array}{c}\text { Miktar } \\
\text { (ton) }\end{array}$ \\
\hline \multirow{3}{*}{ Sığır } & Kültür & 1000 & Et & 150 \\
& Melez & 1400 & & \\
& Yerli & 400 & Süt & 8000 \\
Koyun & & 10000 & Yapağ1 & 10 \\
Keçi & & 3000 & K1l & 4,5 \\
Tavuk (Broiler) & & 41000 & Yumurta & 4 \\
\cline { 1 - 2 } Kovan & Yerli & 50 & Bal & 5 \\
& Fenni & 375 & Balmumu & 1 \\
\hline
\end{tabular}

Kaynak: Gölmarmara Tarım Kredi Koop., 2007

\subsection{Avc1lik}

Son buzul döneminde uzmanlaşmış avcılığa dayalı beslenme biçiminin yaygın olduğu bilinmektedir. Söz konusu dönemde, göl kenarında yaşayan insanların avcılık ve az da olsa toplayıcılık yaptıkları tahmin edilmektedir (Leakey ve Lewin, 2001). Marmara Gölü'nün hemen batı kenarındaki Bintepeler tarihi yerleşiminde avcılık yapıldığına dair kanıtlar bulunmuştur. Bunlar arasında, hayvan öldürmekte kullanılan aletler başta gelmektedir. Yine, insanların bazı hayvanları avlamak amacıyla kuyular kazdıkları da ileri sürülmektedir (Akyıldız, 1975).

Sulak alan etrafindaki sahada Kurt (Canis lupus), Çakal (Canis adustus), Yaban Domuzu (Sus scrofa), Kuyruksüren (Bdeogale crassicauda), Saksağan (Pica hudsonia), Kuzgun (Corvus corax) ve Karga (Corvus bennetti) avı eskiden beri her dönem yapıla gelmiştir. Nisan ve Mayıs aylarının yavrulama zamanı olması sebebiyle bu aylarda avlanma yasaklanmış ve İlçe Orman Mühendisliği ile Jandarma ekipleri özellikle bu aylarda sıkı denetimler yapmaya başlamışlardır. Bu aylar dışındaki diğer zamanlarda yılda genellikle 5 defayı aşmamak şartıyla daha çok sürek avı yapılmaktadır. Bununla birlikte Yarasa (Chiroptera), Kirpi (Erinaceus), Turaç (Francolinus francolinus), Kumru (Columbidae), Kerkenez (Falco naumanni), Çalıkuşu (Regulus regulus), Guguk (Cuculidae), Ağaçkakan (Picus), Çobanaldatan (Caprimulgus europaeus), Sülün (Galliformes), Karatavuk (Turdus merula), Bülbül (Luscinia megarhynchos), Çekirge Kuşu (Lanius), Kırlangıç (Hirundinidae), Leylek (Ciconia ciconia), Puhu (Bubo bubo), Baykuş (Tyto alba) ve Sığırcık (Sturnus vulgaris) gibi 
hayvanların avlanması kesinlikle yasaklanmıştır. Bu yasağa uymayanların ağır cezai işlemlere maruz kalacağı bildirilmiştir. Ayrıca sahada eskiden çokça avlanan Bıldırcın (Phasianidae), Güvercin (Columba livia), Tahtalı (Columba palumbus), Üveyik (Streptopelia turtur), Tavşan (Lepus europaeus), Tilki (Vulpes vulpes), Sansar (Martes foina), Keklik (Alectoris chukar), Çulluk (Numenius arquata), Sakarmeke (Fulica atra) ve Yeşilbaş (Anas platyrhynchos) gibi hayvanların avlanmasına da sınırlamalar getirilmiştir.

Sahada aşırı avlanma sonucunda kuş neslinin yok olma tehlikesi ile karşı karşıya kalınması üzerine, 2008-2009 Av Dönemi Gölmarmara İlçesi Av Komisyon Kararı ilgililerce kabul edilmiş ve yürürlüğe konulmuştur. Kapan, kafes, tuzak, çalı ve her türlü elektronik cihazlarla (teyp, projektör, lüks lambası, far gibi), 1şık kullanarak, pusu kurarak, yumurta ve yavru toplayarak, yırtıcı kuşları kullanarak, otomobil, traktör, motosiklet, tekne ve bot gibi motorlu ve motorsuz araçlar kullanılarak, yivli av tüfekleri hariç, ikiden fazla fişek atan otomatik tüfeklerle avlanmak yasaklanmış olup, özellikle Ozanca, Kayaaltı, Değnekler ve Tiyenli köyleri civarındaki ağaçlandırma sahasında nesli azalmakta olan keklik yavrularının avlanmasının kesinlikle yasak olduğu ve ilgililerce takibi karara bağlanmıştır.

Yasağa karşın sulak alanda kaçak avcılık sürmektedir. Gölün kenarları günümüzde yer yer 50 100 metre genişliğinde sazlıklarla kaplı bulunmaktadır. Bu sazlıklarda bol miktarda görülen Karatavuk (Turdus merula), Sakarmeke (Fulica atra), Kaz (Anser brachyrhynchus) ve Yaban Ördeği (Anas clypeata) en çok avlanan hayvanlar arasındadır (Kambur, 2008). Bu hayvanlar göl etrafındaki yerleşmelerde yaşamını avcılıkla devam ettirmeye çalışan birkaç aile için geçim kaynağıdır. Avlanan bu hayvanların ticari değerinin yanı sıra yerel halkın günlük yaşamlarında yiyecek olarak da önemli bir rolü vardır. Ancak, çoğu zaman bu hayvanlarla birlikte nesli tehlikede olan bazı kuş türleri de avlanmaktadır. Bu olumsuz durum sulak alan ekosistemini tehdit etmektedir.

\subsection{Sazcilik}

Sulak alandaki diğer bir ekonomik etkinlik saz kesimidir. Değiş̧ik ekolojik karakterdeki habitatların varlığı sulak alanı bitki çeşitliliği yönünden zengin kılmıştır. Bu alanlarda su sümbülleri cinsine ait türler hakimdir. Sahada çeşitli çayır otları, Sütleğen (Euphorbia ssp.), Papirus Otu (Cyperus ssp.) ve sazlardan; Hasır Sazı (Juncus ssp.), Çayır Sazı (Carex ssp.), Su Kamışı (Tyhpha ssp.), Böğürtlen (Rubus canascens)'in yanı sıra çeşitli çayır ve otlar ile Bataklık Sazları (Cortaderia Selloana) mevcuttur. Kıyılarda ise daha çok Kamış (Phragmites australis), Saz (Scirpus ssp.) ve Sivri Hasırotu (Juncus acutus) bulunmaktadır.

Sazcılık yörede geçmişte önemli geçim kaynaklarından biriydi. Gölün kenarındaki Sazköy'de bir saz işleme atölyesi bulunmaktaydı. Gölden kesilen sazlar çevredeki il ve ilçe merkezlerinde semer, yastık üreticileri ile ahır yapanlara (nemi çektiği için örtü malzemesi olarak) satılmaktaydı. Bundan yaklaşık 10-20 yı öncesine kadar gölden daha fazla saz kesilmekte ve bu faaliyet yaklaşık 20-30 kişi tarafından yapılmaktaydı. Günümüzde ise yasal olarak birkaç kişi tarafından yapılmakta ve bu kişiler de saz kesimi için gerekli izinleri alarak faaliyetlerini devam ettirmektedir. Bunun yanı sıra her yıl artan miktarda kaçak saz kesimi yapılmaktadır.

Geçmiş dönemde ekonomik koşulların da etkisiyle çiftçiler daha kaliteli saz üretebilmek ve hayvan otlatma koşullarını iyileştirmek için sazlıkların yakılmasına müsaade etmekteydi. Dolayısıyla bu durum sulak alandaki doğal yaşamı olumsuz yönde etkilemekteydi. Daha sonra Gölmarmara, Salihli ve Ahmetli İlçe Çevre ve Orman Mühendislikleri ve Av Komisyonları tarafından alınan kararlara bağlı olarak bu duruma bir sınır getirilmiş, sazlıkların yakılması yasaklanmıştır. Önceki yıllarda sahanın çevresinde bulunan köylüler tarafından aşırı miktarda saz kesimleri olduğu tespit edilmiştir. Bunun üzerine 1993-1995 yılları arasında gölden saz kesimi sürekli olarak yasaklanmış ve bunun denetimi de İlçe Çevre ve Orman Mühendislikleri ile Jandarma ekiplerine devredilmiştir. 1990’lı yılların sonuna doğru göldeki otlanma miktarı oldukça artmış ve sazlıklar da genişlemiştir. Bunun üzerine Hacıveliler, Yeniköy, Sazköy, Kemerdamları ve Pazarköy Muhtarlıkları sazların kesilmesi için Doğa Koruma ve Milli Parklar Şube Müdürlügü’ne müracaat etmiştir. Bu bağlamda, 
Doğa Koruma ve Milli Parklar Genel Müdürlüğü’nün B.18.4.İ̧̧OM.2.04.20-766-797/178 say1lı ve 20.01.2004 tarihli yazısında saz kesimine Sulak Alanların Korunması Yönetmeliği'nin 10. maddesi kapsamında izin verilmiştir.

Günümüzde hemen hemen her yıl genellikle Ekim, Kasım ve Aralık aylarında toplam saz alanının yaklaşık \% 25'i kesilmektedir. Saz kesimi döneminde sık aralıklarla Gölmarmara, Salihli ve Ahmetli İlçe Çevre ve Orman Mühendislikleri ve Jandarma ekipleri tarafından Sulak Alanların Korunması Yönetmeliği çerçevesinde gerekli denetimler yapılmaktadır. Kesilen sazlar ve kamışlar hasır, sepet, sele vb. yapımında, binaların (özellikle de hayvan barınaklarının) çatılarını örtmede ve ahırlarda zemine sermek için kullanılmaktadır. Yazın ise sınırlı ölçüde kesilen sazların bağı pazarlık usulü satılmakta ve bir kısmı da hayvan yemi (yapıldak) olarak değerlendirilmektedir.

\section{Göl Ekosistemini Tehdit Eden Unsurlar}

\section{1. Ötrofikasyon}

Marmara Gölü sığdır ve bol miktarda mineral madde içermektedir. Göl, bu özellikleri itibariyle ötrof (eutrof) göller grubuna girmektedir (Girgin, 2000). Tarımsal gübrelemelerden Marmara Gölü'ne bol miktarda azot ve fosfor bileşiklerinden oluşan besin tuzları gelmektedir. Bunu takiben, bitkisel organizmaların normal gereksinimlerinden daha fazla besin almaları durumu ortaya çıkmakta ve bu durum göldeki bitkiler için gübreleme etkisi yapmaktadır. Bunun yanı sıra göle ulaşan akarsuların getirdiği silt malzemeleri dolma ile birlikte gölün derinliğini azaltmaktadır. Bütün bunlar biyolojik kirlenmeyi (otlanma) hızlandırarak, son iki yılda su üzerinde yaygınlaşan su otlarının gölü istila etmesine yol açmaktadır (Foto 7). Bu durum balıç̧ılık faaliyetlerini olumsuz yönde etkilemektedir. Atılan ağların iyice oturmaması ve yıpranması, tutulan balık miktarında düşmelere yol açmaktadır. Şüphesiz ki, bu durumdan balıkçılıkla geçinen aileler de olumsuz yönde etkilenmektedir.

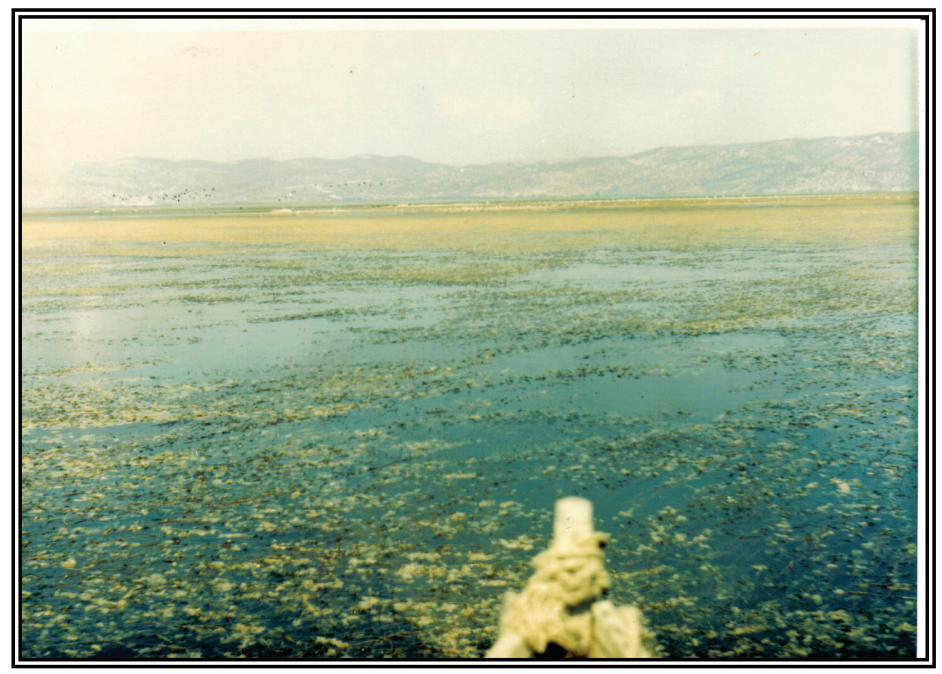

Foto 7. Marmara Gölü’ndeki biyolojik kirlenmeden bir görünüş 


\subsection{Tarımsal Amaçlı Kimyasalların Kullanımı}

Tarımsal ürünlere zarar veren haşerelere karşı kullanılan insectisit ve yabancı otlara karşı kullanılan pestisitler toprakta birikmekte; daha sonra da yıkanma yoluyla yüzey ve taban sularını kirletmektedir. Hatta bu tarımsal ilaçlar (özellikle de DDT, aldrin, dieldrin, endrin, klordone ve heptaklor), yağ dokularında çözünmeleri nedeniyle, kışın kullanılmak üzere vücutlarında yağ tabakası oluşturan hayvanlarda, örneğin balıklarda üreme ve büyüme hızlarını durdurmakta; zehirlenmelere, hatta toplu ölümlere yol açabilmektedir (Kocataş, 2003).

\subsection{Evsel ve Endüstriyel Kaynaklı Kirleticiler}

Sahada daha önceden yapılmış olan çalışmalarda evsel ve endüstriyel kirliliğe değinilmemiş ve bu durum adeta yok sayılmıştır. Burada Gediz Nehri' nin ihmal edildiği görülmektedir. Nitekim bu nehir Kütahya il sınırları içindeki Murat ve Şaphane Dağları' ndan doğmakta; Kütahya, Uşak ve Manisa illerinden geçmektedir. Şüphesiz ki nehire söz konusu bu illerden birçok kirletici karışmaktadır (Sarıtaş, 1992). Bunlar arasında evsel ve endüstriyel kirleticiler de yer almaktadır.

Tarımsal sulama amaçlı kullanılan Gediz Nehri’ nin kirlenmesi sonucunda, nehirden göle yapılmış olan kanallarla aktarılan kirli sular ile Marmara Gölü de bu kirlilikten etkilenmektedir. Bu durum tarımsal ürünlerde verim düşüklüğü ile kendini göstermektedir. Gediz Nehri ve kollarına evsel ve endüstriyel atık suların yeterince arıtılmadan verilmesinin ve katı atıkların denetimsizce atılmasının önlenmesi gerekmektedir. Çünkü Gediz Nehri’nden Marmara Gölü’ ne uzanan kanallarda herhangi bir arıtma tesisi bulunmamaktadır. Marmara Gölü Sulak Alanı'nın bu durumdan olumsuz yönde etkilendiği ve etkileneceği açıktır. 1997 yılında, Marmara Gölü Yönetimi ve Kirlilik Denetimi Fizibilite Etüt Çalışması başlamış ve Ön Fizibilite Çalışması 1999 yılında tamamlanmıştır. Bu çalışma ile suyun yönetiminin sağlanması, optimum ve verimli kullanımının bütün tüketiciler için belirlenmesi, ayrıca bugüne kadar farklı kurum ve kuruluşlarca yürütülen çalışmalarda birliktelik sağlanması, uzun vadede yönetim ve parasal konulara çözüm bulunması hedeflenmiştir.

\section{Marmara Gölü’ndeki Su Yönetimi, Projeleri ve Sorunlar}

\subsection{Projeler}

Bir rezervuara dönüştürülene kadar Marmara Gölü mevsimsel bir göl karakteri taşımaktaydı. 1953 yılında göl kıyısında $10 \mathrm{~km}$. uzunluğundaki sedde inşaatı tamamlanmış ve Gördes ile Kum çaylarının suyu göle yönlendirilmiştir. Gediz Nehri'nin suları da, Adala Regülatörü ile kontrol edilerek göle verilmeye başlanmıştır. Günümüzde Marmara Gölü' nün suları Devlet Su İşleri'nin Aşağ 1 Gediz Sulama Projesi'nin 54875 hektarlık Ahmetli Sulaması dâhilindeki tarım alanlarının büyük bir bölümünü sulamak için kullanılmaktadır. Göl, aynı proje kapsamındaki 28483 hektarlık Menemen Sulaması' na da su sağlamaktadır. Gölün güneydoğu kenarı sedde ile yükseltilmiş ve sulamada faydalanmak için bir regülatör yapılmıştır. Kış aylarında, Kumçayı ve Demirköprü Barajı'ndan ilave su aktarılmaktadır. DSİ Marmara Gölü Regülâtörü’ nden 2006 yılında Gediz Nehri' ne birakılan su miktar1, $328 \times 10^{6} \mathrm{~m}^{31}$ tür (DSİ, 2006).

Güneydoğuda bulunan Adala Regülâtörü'nden göle uzatılan su kanalı, gölün en önemli su kaynaklarından birisini oluşturmaktadır. Güneybatıda yer alan DSİ su boşaltma kapakları ise, gölün ayağını oluşturmakta, aynı zamanda gölden tarım arazilerinin sulamasının sağlandığı ana kaynak özelliği taşımaktadır. Bunun yanı sıra, gölün suları kanallarla güneyde Salihli Ovası ve batıda Kumçay Havzası ovalarını sulamada değerlendirilmektedir. Gölün önceden acı olan sularının, su verme ve alma (dolum-boşaltım) işlemleri sonucunda tatlılaştığı kaydedilmiştir (DSİ, 1983).

Gediz Nehri ile onun bir kolu olan Demrek Deresi'nden ve kuzeydeki Kumçayı'ndan göle bağlanan kanallar yapılmış, gölün doğusundaki bataklık sahanın kenarına bir sedde çekilmiştir. $\mathrm{Bu}$ kanallar akarsuların kabarık zamanlarında göle bol miktarda su taşımaktadır. 


\subsection{Projelerin Yol Açtığı Sorunlar}

Kapalı bir havzada yer alan, küçük derelerle ve yeraltı suyu ile beslenen, mevsimlik, hafif tuzlu bir göl niteliğinde olan Marmara Gölü 1932-1953 yılları arasında yapılan çalışmalar neticesinde bir rezervuara dönüştürülmüştür. Gölün ortalama alanı 3400 ha., derinliği ise 3-4 metredir. Gölün maksimum dolum kapasitesine ulaşması 1960'lı yıllara rastlar (Girgin, 2000). Söz konusu yıllarda göl 6800 hektarlık alan kaplamıştır. Özellikle, 1990'lı yıllar gölün büyük miktarda su kaybettiği yıllardır. Nitekim 1993 yılının yaz mevsiminde, gölün çok büyük bir kısmı kurumuş ve göl şu ana kadar bilinen en küçük halini almıştır. Bunlar sonucunda, daha çok gölün kuzey ve kuzeybatısında bulunan geniş sazlık ve bataklıkların yayılım alanlarında su seviyesine bağlı olan değişmeler gözlenmiştir.

Gölün kapasitesi $320 \mathrm{hm}^{3}$ olup, 3200 ve 6800 ha alana karş1lık gelen 73,6 ve 79.2 metre kotları arasında işletilmektedir. Ancak 1993 yılında, 2 yıllık bir kurak dönemin ardından, çiftçilerin de pompajla su alması ile birlikte su seviyesi 72,6 metreye düşmüş, göl neredeyse kuruma noktasına gelmiş̧ir. Soruna zamanında müdahale edilerek gölden su alımının kesilmesi ve pompayla kaçak su çekiminin durdurulması yoluyla, gölün kurumasının önlenebileceği gerçeği Devlet Su İşleri tarafindan göz ardı edilmiştir. Acil bir çözüm olarak Demirköprü Barajı'ndan (14 no'lu Özel Kuş Alanı) ${ }^{1}$ göle 5 $\mathrm{hm}^{3}$ su bırakılmış, ancak bu uygulama göldeki balık stoklarının yok olmasının önüne geçememiştir. Bunun üzerine 1994 ve 1995 yıllarında gölden sulama için su bırakılmamıştır (DSİ, 1995).

Bilindiği gibi Salihli ve Akhisar, yörenin en gelişmiş kentlerindendir. Salihli aynı zamanda yörede toprak sanayinin (özellikle de tuğla ve kiremit) en gelişmiş olduğu kenttir. Gölün batı kenarından geçmekte olan Salihli-Akhisar karayolu güzergâhı, özellikle de yük taşıtları (tır, kamyon, kamyonet vb.) açısından oldukça işlek bir güzergâhtır. Fazla su dolumu ve yağışlı mevsimlerdeki su seviye yükselmeleri neticesinde, zaman zaman sular karayoluna kadar ulaşmakta ve taşıtlar sular üzerinden gelip geçmektedir. Bunun sonucunda taşıtlardan zaman zaman düşen çeşitli malzemeler (gübre, mermer tozu, tuğla ve kiremit, bitkisel ve hayvansal atıklar vs.) ve taşıtlardan sızan çeşitli kimyasallar (benzin, mazot, motor yağı vs.) suyla birlikte göle karışmaktadır. Bu durum özellikle de gölün batı ve güneybatı kıyılarında daha yaygın olarak görülmekte ve göl açısından önemli bir sorun teşkil etmektedir.

\section{Sonuç}

Marmara Gölü yaklaşık 5000 yıldır insan yerleşmelerine ve kullanımlarına sahne olmuştur. Barındırdığı bütün tehditlere karşın insanların göl ekosistemi ile olan karşılıklı etkileşimi binlerce yıldır devam etmiştir. Günümüzde de göl, sağladığı tarım, balıkçılık, hayvancılık, avcılık ve sazcılık gibi imkânlarla önemli sayılabilecek bir nüfusu ekonomik anlamda desteklemektedir. Göl, sağladığı çeşitli ekonomik etkinlikler yolu ile insanların günlük yaşamlarına adeta damgasını vurmuş durumdadır. Göl olmaksızın bu insanların normal yaşamlarına devam etmesi neredeyse olanaksızdır.

$\mathrm{Bu}$ bölgede tek sulak alan olması nedeniyle bu faydalarının yanında gölün ekolojik fonksiyonu da dikkat çekmektedir. Göl, bu yöredeki su varlığının önemli bir kaynağı olduğu gibi yaban yaşamı için de önemli bir habitat oluşturmaktadır.

Ancak eskiden beri bazı insan faaliyetleri gölün bu işlev ve değerlerini değiştirmişsir. Göl çevresinde eskiden fiziki yapı insan yaşamını ve faaliyetlerini etkilerken, günümüzde insanın bu ekosistemi değiştirmede gösterdiği maharet olağanüstü boyutlara ulaşmıştır. Sürdürülebilir olmayan tarım yöntemleri, su rejimine müdahaleler ve atıklar, göl çevresinde yaşayan nüfusun sayısındaki azalışa karşın önemli tehditler olarak görülmektedir. Bu tehditleri ortadan kaldırmak ve alanı sulak alanların akılcı kullanımı prensipleri çerçevesinde yönetecek sistemli bir planlama maalesef gerçekleştirilememiştir. Dünyada özellikle 1960'lardan sonra sulak alan algısında ve korunması konusunda önemli gelişmeler yaşanırken, Marmara Gölü bir sulak alanın nasıl yönetilmemesi gerektiğinin adeta örneği olmuştur. Alanı yönetmekle ilgili etkinlikler bütüncül bir bakış açısından, ne pahasına olursa olsun tarımsal üretimi artırmak gibi kısır bir amaca indirgenmiştir. $\mathrm{Bu}$ nedenle Marmara Gölü sulak alanını yönetme isteği, alanın su kaynaklarını tarımsal amaçlı kullanmak için 
yapılan düzenlemelerden öteye gidememiştir. Bu ise 1950'lerin "en iyi sulak alan kurutulmuş sulak alandır" sözüyle özetlenen eksik bakış açısını yansıtmaktadır. Türkiye'de sulak alanların korunması konusunda, yasal mevzuatın düzenlenmesi de dahil, oldukça önemli gelişmeler yaşanırken, Marmara Gölü’nde Girgin'in (2000) 10 yıl önce tespit ettiği sorunlar büyük ölçüde devam etmektedir.

Özellikle DSİ'nin yapmış olduğu çalışmalar ile gölün doğal yapısına müdahale edilmiş ve göl 1932-1953 yılları arasında yapılan çalışmalar neticesinde bir rezervuara dönüştürülmüştür. $\mathrm{Bu}$ dönüştürmenin sebep olduğu sorunları gidermek için alanda yeni düzenlemeler yapılmıştır. Ancak bu tür mühendislik çözümleri alanı bütüncül bir ekosistem olarak görmeden planlandığı için başka yerlerde olduğu gibi burada da tahmin edilmeyen problemlere sebep olmakta ve alanın sürdürülebilir kullanımını engellemektedir.

Yönetememe eğiliminin kötü bir yansıması da göldeki besin tuzlarının artışı ile karşımıza çıkmaktadır. Göl etrafındaki köylerden sadece birinde ekolojik tarım yapılmakta; gübre ve ilaç kullanımı denetim altında tutulmaktadır. Ancak diğer yerleşmelerde denetimsiz tarımsal etkinliklerden kaynaklanan tehditlerle ilgili alınmış herhangi bir önlem yoktur. $\mathrm{Bu}$, alanın ekolojik işlevlerine zarar verdiği gibi, ekonomik anlamda da büyük kayıplara neden olmaktadır. Üstelik bu tür düzenlemeler havza bazlı yapılmalı, sadece havzanın bir bölümünde yapılan düzenleme ve düzeltmenin ekosistemin sağlığını temin etmeyeceği göz ardı edilmemelidir.

Marmara Gölü, içinde ve çevresinde barındırdığı biyolojik ve kültürel değerleri ile ender bulunan alanlardan biridir. Göl her şeyden önce günlük yaşamlarında ekonomik anlamda göle bağımlı olan ve çeşitli şekillerde onu kullanan yerel halk için ve yaşamı buradaki habitata bağlı olan yaban yaşamı için korunmalıdır. Gölün barındırdığı canlı yaşamının devamı, gölden faydalanan insanların yaşamlarını sürdürebilmeleri ve geleneksel yaşam biçimlerini devam ettirebilmeleri için gölün sürdürülebilir kullanımının temini esastır. Bunun için gerekli olan siyasal, teknik, idari ve yasal önlemler acilen alınmalıdır.

\section{Notlar}

1. Özel Kuş Alanı: Sağlıklı ve kapsamlı bir çevre koruma stratejisi türlerin, alanların ve habitatların korunmasını ele alır. BirdLife International tarafından geliştirilmiş, uluslararası Önemli Kuş Alanları (ÖKA) yaklaşımı kuş zenginliğinin, dolayısıyla biyolojik çeşitliliğin korunması açısından öncelik taşıyan bölgeler hakkında gerekli temel bilgileri sağlamak yoluyla, alanların korunmasını destekler. Kuşların yaşamları boyunca bulundukları alanların sayısı sonsuzdur. Dolayısıyla, tüm bu alanların etkili bir biçimde korunabilmesi olanaksızdır. ÖKA yaklaşımında, korunmaları ve iyi yönetilmeleri durumunda, kuşların ve biyolojik çeşitliliğin korunmasına en verimli katkıyı sağlayacak öncelikli alanlar belirlenir.

\section{Referanslar}

Adaman, F.; Hakyemez, S.; Özkaynak, B. (2009) “The political ecology of a Ramsar site conservation failure: The case of Burdur Lake, Turkey”, Environment and Planning C: Government and Policy, Advance Online Publication.

Adams, W. M.; Hutton, J. (2007) "People, parks and poverty: Political ecology and biodiversity conservation", Conservation and Society, (5) $147-183$.

Akyıldı, E. (1975) Ege Uygarlıkları, Milliyet Yayınevi, Ankara.

Arı, Y. (2001) Visions of a wetland: Linking culture and conservation at Lake Manyas, Turkey, Ann Arbor, USA.

Arı, Y. (2003a) "Kuş cenneti milli parkı'nda park yönetimi-yöre halkı ilișkisi”, Doğu Coğrafya Dergisi, Sayı: 9 (7 - 37).

Arı, Y. (2003b) “Manyas Gölü’nün kültürel ekolojisi: Tarihi süreçte adaptasyon ve değişim”, Türk Coğrafya Dergisi, Say1 40.

Arı, Y. (2006) "Ramsar sözleşmesi'nin doğa koruma yaklaşımına eleştirel bir bakış, Doğu Coğrafya Dergisi, 11 (15): 275 302.

Çalışkan, V. (2008) "Human-induced wetland degradation: A case study of Lake Amik (Southern Turkey)", Third International Conference on Water Observation and Information System for Decision Support, Ohrid, Macedonia. de Groot, R.; Stuip, M.; Finlayson, M.; Davidson, N. (2005) "Valuing wetlands: Guidance for valuing the benefits derived from wetland ecosystem services", Convention on Biological Diversity Technical Series, 271-54.

DİE. (2007) Nüfus Yillı̆̆l, Ankara.

DSİ. (1983) 2. Bölge Müdürlüğü Marmara Gölü Fizibilite Raporu, İzmir.

DSİ. (1995) 2. Bölge Müdürlüğü Marmara Gölü Fizibilite Raporu, İzmir.

DSİ. (2006) 2. Bölge Müdürlüğü Marmara Gölü Fizibilite Raporu, İzmir.

Dugan, P. J. (1991) Sulak Alanların Korunmast, IUCN (Dünya Koruma Birliği), İstanbul.

Hobbs, J., (1996) "Speaking with people in Egypt's St. Katherine National Park", The Geographical Review. 86 (1): 1-21.

Girgin, M. (2000) "Marmara Gölü", Doğu Coğrafya Dergisi, (3): 77-103.

Gölmarmara Tarım Kredi Kooperatifi. (2007) Yıllık. 
Görmez, K. (1997) Çevre Sorunları ve Türkiye, 2. Basım, Gazi Kitabevi Yayınları, No: 45, Ankara.

Gündoğdu, V.; Torusdağ, E.; Sarıkaya, D. (2005) "Izmir kuş cenneti sulak alanının ekolojik yapısı ve su kirliliği izleme çalışması", Ekoloji, 14, 54, 31-36.

Güney, E. (1992) "İnsanın neden olduğu ekosistem değişiklikleri", İstanbul Üniversitesi Deniz Bilimleri Coğrafya Enstitüsü Dergisi, Say1: 9, 329-335, İstanbul.

Güney, E. (1995) "Türkiye'de sulak alanların çevre sorunları", Türk Coğrafya Dergisi, (30): 41-52.

Gürbüz, M.; Karabulut, M.; Korkmaz, H. (2008) “Gavurgölü bataklığının kurutulmadan önceki kültürel ekolojisi”, Sulak Alan Konferansı Bildiri Kitabı, s. 57-72.

Gürer, İ.; Yıldız, E. (2008) “Türkiye'nin sulak alan politikalarına genel bir bakış: Sultansazlığı sulak alanı örneği”, TMMOB 2. Su Politikaları Kongresi Bildirileri, s. 335-345.

Hoşgören, M. Y. (1983) Akhisar Havzası, İstanbul Üniversitesi Edebiyat Fakültesi Yayınları No: 3088, Edebiyat Fakültesi Basımevi, İstanbul.

İzbırak, R. (1978) Hidrografya, Akarsular ve Göller, Ankara Üniversitesi Dil ve Tarih-Coğrafya Fakültesi Yayınları, Ankara.

Kambur, B. (2008) Marmara Gölü Sulak Alanı'nın Kültürel Ekolojisi, Yüksek Lisans Tezi, Balıkesir Üniversitesi, Sosyal Bilimler Enstitüsü, Coğrafya Anabilim Dalı, Balıkesir.

Karadeniz, N. (2000) "Sultan sazlığı ramsar site in Turkey”, SEHUMED, Humedales Mediterráneos, 1: 107 - 114.

Karadeniz, N.; Tiril, A.; Baylan, E. (2009) "Wetland management in Turkey: Problems, achievements and perspectives, African Journal of Agricultural Research, 4 (11): 1106-1119.

Kocataş, A. (2003) Ekoloji ve Çevre Biyolojisi, Sekizinci Baskı, Ege Üniversitesi Basımevi, Bornova, İzmir.

Leakey, R.; Lewin, R. (2001) Göl İnsanlarl, TÜBİTAK Yayınları, No: 53, Ankara.

Özesmi, U. (1999) Conservation Strategies for Sustainable Resource Use in the Kizilirmak Delta, Turkey, Ph. D. Dissertation, University of Minnesota, USA.

Sarıtaş, F. (1992) “Gediz deltası yönetim planı”, Uluslararası Gediz Deltası Çevresel Kalkınma Semineri Bildiri Metinleri, İzmir, 54-62.

Sulak Alanların Korunması Yönetmeliği. (17 Mayıs 2005) 25818 sayılı Resmi Gazete.

TÇSV. (1989) Türkiye'nin Sulak Alanları, Türkiye Çevre Sorunları Vakfı Yayınları, Ankara.

Tiril, A. (2006) Sulak Alanlar, Peyzaj Mimarları Odası Yayınları: 2006/2, ISBN 9944-89-141-X, 193 s., Ankara.

Tont, S. A. (1997) Sulak Bir Gezegenden Öyküler, TÜBİTAK, Ankara.

Turan, L. (2001) Türkiye'nin Ornitolojik Konumu ve Sulak Alanlar, Hacettepe Üniversitesi Eğitim Fakültesi, Ankara.

Williams, M. (1990) Wetlands: A Threatened Landscape, Cambridge and Oxford: Blackwell.

Yazıcı, H., Şahin, İ .F. (1999) “Demiryurt (Tödürge-Sivas) sulak alanı ve yakın çevresinde coğrafi gözlemler”, Türk Coğrafya Dergisi (34): 19-30.

Yiğitbaşıoğlu, H. (2003) “Burdur Gölü’nün çevre sorunları”, Sırrı Erinç Sempozyumu Genişletilmiş Bildiriler Kitabı, İstanbul, s. 182-185. 